\title{
Subjektien tilallinen paikantuminen Zadie Smithin romaanissa White Teeth
}

\section{Koordinaateiksi}

Tämän artikkelin tarkoituksena on tutkia tilaa sukupuolen ja etnisyyden merkityksellistäjänä brittiläisen kirjailijan Zadie Smithin (s.1975) esikoisromaanin White Teeth (2000, suom. Valkoiset hampaat) luennan kautta. Smithin romaani herätti ilmestymisajankohtanaan laajaa mediahuomiota ja se keräsi kriitikoilta paljon kiitosta muun muassa monikulttuurisen yhteisön syvällisen ja vivahteikkaan kuvauksen vuoksi (ks. esim. Tew 2010, 13; Squires 2002, 69-78; Walters 2008, 1). Romaania verrattiin muun muassa Salman Rushdien moniaineksisiin ja -tasoisiin teoksiin, ja Smithin teosta onkin paikannettu yhdeksi mustan brittiläisen nykykirjallisuuden merkittävimmäksi edustajaksi (ks. esim. Walters 2008, 1; Ellam \& Woodward 2013). Romaanin moninaisuus on tarjonnut tutkijoille runsaasti tarttumapintaa. Suurelle osalle White Teeth -tutkimusta on ollut yhteistä jälkikoloniaalinen tutkimusote ja niinpä kysymykset etnisyydestä, monikulttuurisuudesta ja hybridiydestä ovat selkeästi dominoineet teoksesta tehtyä tutkimusta (vrt. Buchanan 2013, 13). Viime aikoina teokseen on haettu uusia näkökulmia muun muassa uskonnollisen identiteetin problematiikan tutkimisen (Mirze 2008), posthumanismin (Buchanan 2013) ja modernismin sekä postmodernismin (Paproth 2008) kysymysten kautta.

White Teeth kertoo vuosituhannen vaihteen monikulttuurisesta Lontoosta kolmen erilaisen - juutalais-brittiläisen, karibialais-brittiläisen ja aasialais-brittiläisen - perheen kautta. Samalla teksti liikkuu useilla eri aika- ja tilatasoilla niin, että teoksessa tematisoidut kysymykset etnisyydestä ja sukupuolesta ovat useimmiten selvästi kytköksissä johonkin tiettyyn tilaan. Sukupuoli ja kulttuurinen moninaisuus onkin usein nähty teoksen keskeisinä teemoina, vaikka toki näiden rinnalla romaani käsittelee muun muassa kohtaloon, sattumaan ja valinnanvapauteen liittyvää problematiikkaa sekä sukupolvikysymyksiä ja historiaa (ks. esim. Squires 2002, 23-24, 43-55; Dawson 2007, 149-173). Tässä artikkelissa jatketaan sukupuolen ja etnisyyden yhteenniveltyneen suhteen ja niitä koskevan tiedon rakentumisen tarkastelua, mutta subjektipositioihin paikantuminen nähdään ennen kaikkea tilallisena ilmiönä. Tästä syystä myös tilan käsite nousee tarkastelun keskiöön.

Viime vuosikymmeninä intersektionaalisuudesta on tullut yksi sukupuolentutkimuksen ja feministisen tutkimuksen keskeisimmistä käsitteistä (ks. esim. Karkulehto, 
Saresma, Harjunen \& Kantola 2012, 17-28; Lykke 2010). Intersektionaalisuudella viitataan siihen, miten erilaiset sosiaalisesti, kulttuurisesti ja historiallisesti tuotetut identiteettikategoriat, kuten sukupuoli, seksuaalisuus, ikä, uskonto ja luokka, ovat aina kytköksissä toisiinsa. Niiden merkitykset muodostuvat keskinäisessä vuorovaikutuksessa ja niinpä näitä eri tekijöitä ei tulisikaan käsitellä erillisinä tai olemukseltaan essentiaalisina (Valentine 2007, 12). Subjektit paikantuvat aina osaksi lukuisia erilaisia merkityksellisiä kategorioita, ja esimerkiksi sukupuoli saa erilaisia merkityksiä kytkeytyessään etnisyyteen tai seksuaalisuuteen. Sukupuolentutkimuksessa ja feministisessä tutkimuksessa on pohdittu runsaasti paikantumisen/paikantamisen problematiikkaa ja esitetty, että tieto ja sen tuotanto ovat aina paikantuneita (Lykke 2010, 4; Haraway 1988, 575-599). Paikantuminen ei ole yksinkertaista ja ongelmatonta tilaan, sukupuoleen tai muihin kategorioihin asettumista ja asettamista. Sen sijaan siinä on kyse monimutkaisesta omaehtoisen paikantumisen ja subjektin ulkopuolisten paikantamisyritysten ristiliikkeestä. Artikkelissa selvitetään paikantumisen ambivalenttia prosessia, jossa subjektit diskursiivisesti konstruoidaan. Subjektius onkin prosessi, johon liittyvät monenlaiset valta-asemat (ks. esim. Rossi 2010, 30, 32). Subjektista puhuttaessa ei voida myöskään jättää huomiotta ruumiillisuutta ja sitä, että subjekti on myös ruumiillinen olento (Rossi 2010, 32; Palin 2004 225-242). Ruumis sijaitsee aina konkreettisesti jossain tilassa, se on tilaan paikantunut niin, että ruumis ja tila rakentuvat niiden keskinäisessä suhteessa (Palin 2004, 240). Ruumis on yhtä aikaa sekä materiaalinen että metaforinen ja juuri sen kautta sukupuolen ja etnisyyden merkitykset usein konkretisoituvat.

Tilaa yhdessä (muiden) intersektionaalisten muuttujien kanssa on tähän saakka tarkasteltu lähinnä feministisesti orientoituneen maantieteen piirissä (Massey 2008; McDowell \& Sharp [eds.], 1997). Tila on pitkään ymmärretty pelkkänä ihmisten toiminnan taustana ja eräänlaisena merkityksistä tyhjänä todellisuutemme näyttämönä (ks. esim. Tally 2013, 28-30). Tällaista abstraktin tilan käsitettä ovat ravistelleet kuitenkin useat filosofit ja kulttuurintutkijat, jotka ovat tuoneet esiin ajatuksen tilasta nimenomaan elettynä kokonaisuutena ja näin ollen painottaneet sen sosiaalisesti tuotettua luonnetta (Buchholz \& Jahn 2005, 553; Lefebvre 1991). Se, miten subjektit määrittyvät ja miten heidät määritellään, on riippuvainen paitsi esimerkiksi sukupuolesta tai etnisestä taustasta sekä näiden muuttujien intersektioista, niin myös tilasta, kuten erityisesti monet jälkikoloniaalisen tutkimuksen parissa operoivat tutkijat ovat huomauttaneet (Ashcroft, Griffiths \& Tiffin, 1995, 391; Teverson \& Upstone, 2011,1-4). Tilan ja merkitysten rakentumisen välillä onkin kiinteä suhde; subjektien paikantuminen osaksi erilaisia merkitysjärjestelmiä on tilallinen ilmiö. Tilaa koskevassa kysymyksenasettelussa ei pyritä vain paikallistamaan esimerkiksi sukupuolten tiloja tai tilan sukupuolta dikotomisessa mielessä (vrt. Higonnet 1994, 2) vaan sen sijaan pyritään tarkastelemaan tilallisen kiinnittymisen kautta rakentuvia hetkellisiä subjektiuksia ja identiteettejä eli paikantumisia. 
Mitä sitten ovat nämä kirjalliset tilat? Reaalimaailman "faktuaalisten" tilojen lailla niitäkään ei voida pitää merkityksistä tyhjentyneinä miljöinä tai pelkkinä tapahtumapaikkoina. Kirjallisuuden tiloja ei voida myöskään - kuten ei kaunokirjallisuutta yleensäkään - suoraan palauttaa todellisiin paikkoihin tai pitää niiden heijastuksina (Kurikka 1998, 7; Tally 2013, 52), mutta silti niiden avulla on mahdollista ymmärtää ja pohtia omaa maailmaamme (Tally 2013, 6, 42). Jälkikoloniaalisen romaanin tilan politiikkaa tutkinut Sara Upstone (2009) onkin analysoinut tilaa ennen kaikkea filosofisena käsitteenä. Filosofisella tilalla Upstone $(2009,3)$ tarkoittaa sitä, että tilaa ei tulisi ymmärtää pelkästään konkreettisena sijaintina; sen sijaan filosofinen tila näyttäytyy kattokäsitteenä, joka pitää sisällään sellaisia toisia spatiaalisia käsitteitä kuin paikka, sijainti tai siirtymä.

Filosofinen tila tarkoittaa tilan sosiaalisesti tuotetun merkityksen ymmärtämistä sekä toisaalta tilan merkityksiä tuottavan puolen näkemistä (Upstone 2009). Tilan eri tasot - fyysiset ja metaforiset - eivät ole toisistaan erillisiä (vrt. McDowell 1999, 4) vaan limittyvät toisiinsa ja ovat vuorovaikutuksessa keskenään. Tähän tilan käsitteellistämisen tapaan ovat ainakin osin sidoksissa sellaiset tarkastelutavat, joissa ollaan kiinnostuneita niistä kirjallisuuden representoimista tilallisista prosesseista, joissa sukupuoleen ja etnisyyteen liittyviä kategorisointeja voidaan sekä konstruoida että purkaa ja kirjoittaa uudelleen. Kaksi keskeistä käsitettä tarkastellessani tilan konkretiaa ja metaforisuutta ovat Michel Foucault'n utopia ja heterotopia (Foucault 1986, 24). Foucault'n (1986) mukaan utopiat ovat paikkoja, jotka eivät ole fyysisesti, konkreettisesti olemassa. Sen sijaan niillä toki on viittauskohde todellisuuteen, sillä ne saattavat esittää yhteiskunnan utopistisessa, täydellistyneessä muodossa tai esimerkiksi eri tavoin nurin kurin käännettynä. Heterotopiat puolestaan ovat paikkoja, jotka todella ovat olemassa mutta joissa kaikki muut paikat voidaan esittää, kiistää tai kääntää ylösalaisin. Heterotopiat siis pitävät sisällään kaikki muut paikat, ja vaikka niiden sijainti voidaan konkreettisesti osoittaa, niin edellä mainitun vuoksi ne ovat myös kaikkien paikkojen ulkopuolella.

Tässä artikkelissa selvitetään, miten White Teeth -romaanissa käsitellään yhteisiä tieto- ja merkitysjärjestelmiä, jotka koskevat kulttuurisesti jaetuksi oletettua tietämystä sukupuolesta, seksuaalisuudesta ja etnisyydestä. Artikkelini rakentuu pääosin kolmen tietämistä koskevan "you know" -ilmaisun sekä niihin liittyvien välimerkkien ympärille. Esitetäänkö teoksessa juuri näiden tietämistä koskevien ilmaisujen kautta jotain oleellista sukupuolen ja etnisyyden tilaan sidoksissa olevasta rakentumisesta?

\section{"You know..." \\ Hegemonisen paikantamisen kritiikki}

'You see the wives don't like it because, let's face it, she's a sort, a real beauty

- incredible legs, Archie, I'd like to congratulate you on them legs - and the 
men, well, the men don't like it 'cos they don't like to think they're wanting a bit of the other when they're sitting down to a company dinner with their lady wives, especially when she's... you know... they don't know what to make of that all.' (White Teeth, 72; tästä eteenpäin WT; sitaatin kursivointi alkuperäinen.)

Yllä olevassa kohtauksessa romaanin yhden keskeisimmän henkilöhahmon, Archie Jonesin, esimies toimitusjohtaja Kelvin Hero, yrittää vaivautuneena ${ }^{1}$ selittää Archielle, ettei tämän vaimon, Clara Jonesin, ole soveliasta osallistua yhtiön järjestämille illallisille. Syy, miksi Clara ei ole - varsin ironisesti nimetyn - Kelvin Heron mukaan toivottu vieras, on Claran ihonväri ja karibialais-englantilainen tausta. Hero mieltää Claran aivan sananmukaisesti eksoottiseksi ja eroottiseksi Toiseksi ("other"), joka herättää pelkällä olemassaolollaan miehissä epäsoveliasta halua. Hero tulkitsee mustan ihon ja muiden ruumiin merkkien, (nais-)sukupuolen ja kenties nuoren iänkin ${ }^{2}$ yhdistelmän merkitsevän seksuaalisuutta, joka uhkaa illallistapahtuman tasapainoa. Toimitusjohtaja Heron puheessaan esittämä huomautus siitä, että Archien pitäisi tietää kursiivi vielä korostaa tietämistä koskevan oletuksen oikeutusta - mitä Hero tarkoittaa ("you know..."), viittaa Claran ihonväriin, joka erottaa hänet muista, valkoisista, hienoista rouvista ("lady wives"). Samalla Heron puhe implikoi ajatusta valkoisten naisten seksuaalisuuden normaaliudesta, puhtaudesta ja (aviollisesta) hallittavuudesta. Valkoiset naiset ovat seksuaalimoraalisesti vaarattomia toisin kuin Clara, jonka pelkkä läsnäolo illallisilla kohdistaa oletetun uhan yhtiön miestyöntekijöiden ja näiden puolisoiden välisiin suhteisiin. Huomionarvoista kuitenkin on, että itse asiassa Archie ei ymmärrä alkuunkaan, mistä Hero puhuu ja keneen hän viittaa:

'Who?'

'What?'

'Who are we talking about, Mr Hero?' (WT, 72.)

Archie ja Hero eivät jaa samaa (sukupuolittavaa, seksualisoivaa ja rodullistavaa) merkitysjärjestelmää ja niinpä Heron sanat eivät Archielle viittaa Claraan vaan tällainen mustan naisen rodullistava ja seksualisoiva diskurssi näyttäytyy käsittämättömänä. Kolme pistettä "you know" -ilmaisun perässä merkitsevät katkosta ja epävarmuutta jaetusta ymmärryksestä.

Heron kautta esitetään toinenkin sukupuolia koskeva kulttuurinen stereotypia: hänen puheessaan nimenomaan miehet märittyvät työntekijöiksi ja toimijoiksi, kun taas naiset määritellään suhteessa miehiinsä ja heidän kauttaan eli vaimoina ja puolisoina. Kun Hero onnittelee Archieta uskomattoman hienon sääriparin hankinnasta, tulee hän samalla pelkistäneeksi koko Claran ihmisyyden tähän samaiseen ruumiinosaan. ${ }^{3}$ Viittaus säripariin ei ole viaton kohteliaisuus, sillä naisen sääret ovat kulttuurisessa kuvastossamme vahva feminiinisyyden ja seksuaalisen haluttavuuden merkki (ks. esim. Rossi 2003, 37). Lisäksi tällainen ihmisyyden redusoiminen johonkin fyysiseen 
ominaisuuteen tekee siitä markkinatavaraa, jotain joka voi vaihtaa omistajaa ja jonka hallinta voidaan saada tai luovuttaa pois. Sinällään Archien onnitteleminen sääristä kuin mistäkin voitonmerkistä on tietysti mitä komediallisin kuva. Heron henkilöhahmon välityksellä tapahtuva rodullistavan diskurssin liioittelu mahdollistaakin juuri tuon diskurssin parodioinnin ja jopa sen karnevalistisen representaation. On syytä huomata, että esimerkissäni representoitu seksualisoiva diskurssi ulottuu miehiinkin, sillä heidät saadaan näyttämään halujensa armoilla olevilta reppanoilta, joita täytyy suojella yllykkeiltä sekä niiltä epämiellyttäviltä tunteilta, joita Toisen haluaminen heissä aiheuttaa. ${ }^{4}$ Smithin teoksesta välittyykin vahva tietoisuus niistä useista erilaisista tasoista, joilla sukupuolen ja seksuaalisuuden diskurssit liikkuvat.

Teoksessa yhtiön illallista kuvataan Kelvin Heron mukaan vapaamuotoiseksi, lähes arkiseksi tapahtumaksi; luvassa on vain vähän currya, olutta sekä "boogieta" (WT, 72). Illallinen on rento tilaisuus, mutta samalla se on kuitenkin varsin ambivalenttia aluetta, sillä toisaalta se kutsuu rentoutumaan, mutta toisaalta siellä vallitsevat tarkat sosiaalisen kurin ja järjestyksen vaatimukset. Illallistilaisuus on muodollisen työn ja epämuodollisen vapaa-ajan yhdistelmä, jossa kahden erilaisen tilan liitos aiheuttaa epävarmuutta Heron kaltaisissa henkilöhahmoissa. Rentoutuminen on siis mahdollista vain, mikäli tietyt osallistujia koskevat ehdot toteutuvat. Illallissali on myös rodullistettu tila, sillä perinteisesti mustat naiset on paikannettu keittiöön, kulissien taakse palvelemaan valkoista väkeä. Tilassa muotoutuu tiukan - erityisesti seksuaalimoraalisen - kontrollin vaatimus, jossa Claran sukupuolitettu, rodullistettu ja seksualisoitu hahmo näyttäytyy uhkana. Tämä uhka täytyy rajata tilan ulkopuolelle, jottei se rikkoisi sen (näennäistä) harmoniaa.

Myös sillä, kuka puhuu, on "you know..." -lausahduksen tapauksessa suuri merkitys. Claraa pyritään tässä määrittelemään ja merkityksellistämään nimenomaan ulkoapäin, koska puhujana toimii Hero. Hän määrittyy - hierarkkisesti järjestynein binaarisin oppositioparein ajateltuna - usealla tavalla Claran vastakohdaksi: sen lisäksi, että Hero on mies ja valkoinen, poikkeaa hän nuoresta Clarasta myös ikänsä ja sosiaalisen luokkaasemansa perusteella. Nämä kaikki intersektionaaliset muuttujat paikantavat Heron hierarkkisesti Claraa ylempään asemaan. Tämä Heron "ylemmyys" asettuu kuitenkin varsin kyseenalaiseksi, sillä hän epäröi ja empii asiansa esittämisessä Archielle ja itse asiassa käyttäytyy täysin päinvastaisesti kuin varman, voimakkaan ja hyvän johtajan - tai sankarin - idealisoituun kulttuuriseen kuvaan kuuluu. Tähän viittaa, kuten aiemmin mainittu, myös hänen ironinen nimensä. Heron horjunta Enoch Powellin ${ }^{5}$ kannatuksen ja oman rasisminsa ${ }^{6}$ kieltämisen välillä saa hänet vaikuttamaan epäuskottavalta valehtelijalta:

[- - ] ....as I say, it's not that I'm a racialist, Archie...'

'A racialist...' 
'I'd spit on that Enoch Powell...but then again he does have a point, doesn't he? There comes a point, a saturation point, and people begin to feel a bit uncomfortable...' [--] (WT, 72.)

Heron auktoriteetti ja johtajuus puretaan lopullisesti hänen lausahduksensa "You see the wives don’t like it” [- - (WT, 72) myötä, sillä mikä olisikaan kulttuurisesti sen pelkurimaisempana pidettävää toimintaa kuin syyn ja vastuun vierittäminen toisten niskoille. Heron keino ratkaista tukala tilanne on sekin niin ikään omiaan kyseenalaistamaan Heron representoiman sukupuolta, seksuaalisuutta ja etnisyyttä koskevan toiseuttavan merkitysjärjestelmän oikeellisuuden: Hero lahjoo itsensä ulos tilanteesta tarjoamalla Archielle nipun lounasseteleitä. Claran toiseuttava järjestelmä asetetaan rinnakkain korruption kanssa, jolloin tuo järjestelmä on yhtä läpimätä kuin Heron harjoittama lahjonta. Claran nimi puolestaan viittaa latinaksi vaaleaan, kirkkaaseen ja suosittuun. Dikotomioiden 'valkoinen mies ja musta nainen' merkitykset kammetaan pois totutuilta paikoiltaan nimisymboliikan avulla. Herolle seksuaalisesti haluttavana, mutta samalla epäilyttävänä ja torjuttavana näyttäytynyt Clara paljastuu nimensäkin kautta puhtaaksi näistä Heron kuvitelmista. Näin romaanissa kyseenalaistetaan hegemoninen sukupuolta, seksuaalisuutta ja etnisyyttä koskeva merkitysjärjestelmä, joka rajaa tietyin ominaisuuksin (nainen, musta) merkityt subjektit Toisiksi. Esimerkissä juuri tila - illallistilaisuus - toimii tämän toiseuttavan, hegemonisen merkitysjärjestelmän paljastajana.

\section{"Oh, you know her"}

\section{Assimiloivan paikantamisen kyseenalaistuminen}

This has been the century of strangers, brown, yellow and white. This has been the century of the great immigrant experiment. It is only this late in the day that you can walk into a playground and find Isaac Leung by the fish pond, Danny Rahman in the football cage, Quang O'Rourke bouncing a basketball, and Irie Jones humming a tune. Children with first and last names on a direct collision course. Names that secrete within them mass exodus, cramped boats and planes, cold arrivals, medical checks. (WT, 326.)

Tätä kohtaa on siteerattu runsaasti teoksesta jo tehdyissä analyyseissa, kun on haluttu kiteyttää jotain oleellista sen tematiikasta (vrt. esim. Squires 2002, 23; Tancke 2013, 32; Bentley 2007, 14; Moss 2003, 14). Vaikuttaisikin siltä, että White Teethin Lontoo on tila, jota asuttavat erilaisin etniseen taustaan liittyvin eroin merkityt subjektit. Nämä leikkipaikan lapset ravistelevatkin valkoisen ja homogeenisen englantilaisen kansakunnan ideaa (vrt. Bentley 2007, 496). Kyseessä ei kuitenkaan ole vain "rauhallinen ja tylsä” monikulttuurisuuden kuvaus, jossa vain vilahtaa ikäviä kolonialismin muistoja sekä monikulttuurisen tulevaisuuden pelkoja, tai ainakin tämä on liian suoraviivainen kuvaus (vrt. Moss 2003, 14). Lapset määrittyvät nimenomaan muukalaisiksi, kuten myös kertoja eksplisiittisesti toteaa, eli tilan ja ihonvärin ristisiitos tekee heistä tämän 
tilan vieraita, Toisia. Kiinnostavasti kertoja lisää muukalaisten väripalettiinsa myös valkoisen, jolloin ajatus ihonväristä tilaan kuulumisen tai ulkopuolisuuden merkitsijänä paljastuu keinotekoiseksi. Valkoinen rinnastuu yhtä lailla vierauteen ja outouteen kuin ruskea ja keltainen. Näin perspektiivi, josta outoutta ja toisaalta tuttuutta/normaaliutta arvioidaan, käännetään tekstuaalisen strategian - rinnastuksen - kautta pälaelleen: myös valkoinen voi merkitä vierautta. Teksti tulee ehdottaneeksi eräänlaisen implisiittisen fokalisoijan ${ }^{7}$ paikalle sitä, joka ennen on ollut katseen objektin asemassa: entisen siirtomaan asukasta, ei-valkoista tai vaikkapa karibialais-englantilaista lontoolaista.

Myöskään "siirtolaiskokeilua" ei tarvitse tulkita vain niin, että se viittaisi Englantiin saapuneisiin, usein ei-valkoisiin, entisten siirtomaiden asukkaisiin. Itse asiassa edeltävän, valkoisuus-vieraus-virkkeen jälkeen on jopa varsin perusteltua ehdottaa, että siirtolaiskokeilukin viittaa siirtomaaisäntien itsensä - valkoisten englantilaisten - harjoittamaan siirtolaisuuteen. Näin teksti kyseenalaistaa myös vakiintuneet käsitykset siitä, kuka on siirtolainen, vaikka se samanaikaisesti kykeneekin havainnoimaan (pakotettuun, entisten siirtomaiden asukkaita kohdanneeseen) siirtolaisuuteen liittyvät kipupisteet kylmine saapumisineen ja lääkärintarkastuksineen. Leikkikenttä ${ }^{8}$ toimii siis leikin paikkana myös metaforisella tasolla: siellä heittävät kärrynpyörää ja joutuvat myllerrykseen erityisesti muukalaisuutta, outoutta ja vierautta koskevat diskurssit; oletettu tieto vieraudesta siitä kuka tuo muukalainen, toinen on - kyseenalaistuu. Itse asiassa leikkikentällä ei ainoastaan käännetä ylösalaisin kolonisoitu/kolonisoija-asetelmaa vaan se puretaan, sillä lapset eivät enää solahda näihin lokeroihin (vrt. Bentley 2007, 496). Näin leikkikentästä tulee juuri se "kolmas tila" (vrt. Soja 1996), jossa vanhat kaksinapaisuudet eivät enää päde.

Ruumis on mikrotason tila, jossa yhdistyvät niin fyysiset (joskin muunneltavissa olevat) tilat, kuvitellut tilat kuin temaattiset tilatkin. White Teeth-romaanissa teiniikäinen Irie Jones yrittää päästä eroon afrotukastaan ja runsaasta vartalostaan. Hänen äitinsä yrittää vakuutella, ettei Iriessa tai tämän vartalossa ole mitään vikaa, mutta " [- - ] Irie didn't know she was fine. There was England, a gigantic mirror, and there was Irie, without reflection. A stranger in a stranger land.” (WT, 266.) Mikrotilana ruumis on väistämättä jossain suhteessa sen ulkopuolella diskursiivisesti käytyihin neuvotteluihin ruumiin normeista ja rajoista.

Edellisestä sitaatista erottuu toinenkin tila, nimittäin peili. Michel Foucault’n (1986, 24) mukaan peili on eräänlainen utopian ja heterotopian sekoitus. Peili on utopia siinä mielessä, että se on paikaton paikka, jossa ihminen näkee itsensä siellä, missä hän ei ole; peilin pinnan takaisessa tilassa, jota ei todellisuudessa ole. Foucault'n $(1986,24)$ sanoin peili mahdollistaa sen, että ihminen näkee itsensä siellä, missä hän ei ole. Tässä tapauksessa Irien ruumiille ei sananmukaisesti tunnu löytyvän tilaa paikasta/peilistä/ Englannista, jossa vallitsee normatiivisen valkoisen, liehuvahiuksisen, hoikan naisruumiin ihanne. Näin ollen Irien vartalo merkitsee hänet poikkeukseksi, Toiseksi. ${ }^{?}$ 
Irielle peili eli Englanti ei heijastakaan mitään takaisin, hän ei näe siinä itseään vaan peilistä tulee poissaolon merkitsijä. Raja kuulumisen ja kuulumattomuuden/läsnäolon ja poissaolon välille on ihoon ja ruumiin kaariin kirjoitettu. Tässä tilassa musta tarkoittaa yhteisen rakenteellisen paikantamisen jakamista: rodullistetun paikantamisen (Mirza 1997, 3). Jos peili kuitenkin on "paikaton paikka" (Foucault 1986, 24), niin kuinka todellinen on se Englanti, joka peilinä toimii? Tietysti Englanti - tai tila, jota sillä nimellä kutsutaan - on fyysisesti olemassa, mutta kuinka todellinen on se kuviteltu Englanti, joka estää Irien itsen heijastuksen?

Yllä olevasta lainauksesta voidaankin lukea esiin tällaisen eksklusiivisen Englannin ja etnistä toiseutta tuottavan tilan kritiikkiä sitaatissa käytetyn komparatiivimuodon vuoksi: jos Irie tunteekin itsensä oudoksi muukalaiseksi, niin maa, jossa hän sellaiseksi itsensä tuntee, on vielä oudompi. Tosiasiassa kansakunta tai maa on aina väistämättä varsin heterogeeninen kokonaisuus vailla ehdotonta alkupistettä tai olemusta (mm. Upstone 2009, 4; Lehtonen \& Löytty 2007, 105-118). Peilin Englanti näyttäytyykin nimenomaan utopiana, paikkana, jota ei todellisuudessa ole olemassakaan. Foucault $(1986,24)$ toteaa, että peili on kuitenkin myös heterotopia, sillä fyysisenä esineenä se todella on olemassa ja sen kautta siitä paikasta, jossa ihminen on katsoessaan itseään peilistä, tulee samanaikaisesti sekä todellinen että epätodellinen. Niinpä peilin vaikutukset ovat Iriellekin todellisia; ne johtavat siihen, ettei hän tunnista itseään. Peilin heterotopiassa katsoja katsoo itseään takaisin peilin epätodellisuudesta, katse palautuu omaan itseen ja alkaa näin ollen uudelleen muodostaa minää siellä, missä minä on (fyysisesti, ei peilissä). Näin ollen peilin heterotopia sekä on että ei ole todellinen paikka: se paikka, jossa minä peiliin katsoessaan on, on todellinen - ja samalla yhteydessä kaikkiin muihin ympäröiviin paikkoihin - mutta havainnoidaksemme tätä paikkaa, on havainnon kuljettava peilin "epätodellisuuden" (Englanti-kuvitelman) kautta.

Peilin epätodellisuus on myös Irien kuvitteleman Englannin epätodellisuutta, sillä se englantilainen naisvartalo, jonka Irie kuvittelee, on yksipuolisuudessaan mahdottomuus, jonka puolesta jo pelkkä Irien läsnäolokin todistaa: "[- - English Rose - oh, you know her - she's slender, delicate thing not made for the hot suns, a surfboard rippled by the wave" (WT, 267). Täälläkin toistuu tietämistä koskeva puhuttelu ("oh, you know her"). Nyt tosin puhuttelija on kertoja, joka kutsuu lukijaa tunnistamaan kulttuurisesti jaetun "englantilaisen ruusun" eli aidon, englantilaisen (valkoisen) naisen kuvan. Ruusulla on aivan erityinen merkitys englantilaisuuden ja sen, mitä pidetään englantilaisena kulttuurina, rakentumisen kannalta. Ruusu toistuukin vahvan merkityssisällön omaavana kuvana niin taiteissa, historiassa kuin populaarikulttuurissakin aina ruusujen sodasta Tennysonin runouden kautta Elton Johnin Candle in the Wind -lauluun. ${ }^{10}$ Sinänsä juuri ruusu aidoimman, puhtaimman ja haluttavimman englantilaisen naisen metaforana on luonteeltaan ambivalentti: useimmat ruusulajikkeet kun ovat lähtöisin Aasiasta ja vain vähemmistö on Euroopasta ja Pohjois-Amerikasta (Encyclopaedia Britannica 2014). Sen 
sijaan ruusut kyllä risteytyvät keskenään varsin vaivattomasti ja alkuperäistä lajia voikin olla huomattavan vaikea tunnistaa! (mt.) "Oh, you know her" -ilmaisun implikoima tietämisen oletus siitä, mihin (tai millaiseen naiseen) englantilaisella ruusulla kulttuurisessa kuvastossamme viitataan, saattaa sinänsä olla oikeutettu, mutta englantilaisen ruusun "todellisuus" - toisin sanoen englantilaisen naisen ihannekuva, eräänlainen vastastereotypia - asettuu kyseenalaiseksi jo helposti ja toisteisesti lausutun "Oh, you know her" -ilmaisun myötä. Saman ilmaisun - joka aiemmin on viitannut juuri siihen, ettei välttämättä ole mitään yhteisesti jaettua merkitysjärjestelmää - toistuminen saa epäilemään tässäkin yhteydessä, onko englantilaista ruusua todella, lihaa ja verta olevana, edes olemassa.

Toisin kuin ensimmäisen "you know..." -ilmaisun tapauksessa, nyt tietämistä koskevan huomion esittää kertoja. Edelleen kulttuurisesti hyväksyttävää naiseutta koskevat määrittelyt ja huomiot, paikantamiset, esitetään ulkoapäin, nyt tosin valkoisen mieshenkilöhahmon ääni on vaihtunut kertojan ääneksi. Koska annetun tiedon perusteella ei voi sanoa mitään kertojan mahdollisesta sukupuolesta tai muistakaan määreistä, on tässä tapauksessa tyytyminen toteamukseen kerronnallisesta ulkopuolisuudesta ${ }^{11}$ suhteessa kuvauksen kohteisiinsa, joita ovat sekä musta, nuori nainen (Irie Jones) että valkoinen, englantilainen nainen (ruusu). Esimerkit paljastavat subjektien paikantamista koskevan assimiloivan, sulauttamaan pyrkivän, erot ja moninaisuuden häivyttävän, tendenssin. Samalla niistä voidaan kuitenkin lukea esiin niiden raamien kyseenalaistuminen, joihin "outo" ja "vieras" pyritään sovittamaan.

\section{"You know?"}

\section{Paikantumisen avoimuus}

Subjektia koskevien määrittelyjen lausujina ovat olleet tähän saakka muut kuin ne, joita nuo merkityksellistämisen prosessit koskevat. Miten siis puhuvat ne, jotka eivät vielä ole ääntänsä kuuluviin saaneet? Irie Jones kaipaa tyhjää tilaa, jossa menneet huoneet ja niiden sokkelot eivät sekoita ihmisten nykyisyyttä:

What a joy their lives must be. They open a door and all they've got behind it is a bathroom or a lounge. Just neutral spaces. And not this endless maze of present rooms and past rooms and the things said in them years ago and everybody's old historical shit all over the place. [- - ] And every single fucking day is not this huge battle between who they are and who they should be, what they were and what they will be. [- - No attics. No shit in attics. No skeletons in cupboards. No great-grandfathers. (WT, 514-515.)

Tilassa, jossa Irie elää, hän joutuu jatkuvasti kamppailemaan etnisen taustansa ja sukupuolensa tuottaman eron tunteen kanssa. Toisaalta Irien toive neutraalista tilasta ei ole mahdollinen siinä mielessä, että nykyisyys rakentuu aina menneisyydelle, sillä lopulta kaikilla ihmisillä on "isoisänisänsä”. Irie ei tunnista aluksi, että hän tällä tavoin tulee 
jo muuttaneeksi tilaa, ei tosin neutraaliksi, mutta sellaiseksi, jossa hänellekin löytyy peilikuva. Tällaista "kolmatta tilaa" kuvataan jälkikoloniaalisessa tutkimuksessa usein "luovan hybridiyden ja omaperäisten uusien ideoiden" tilaksi, jonka avulla vastakohtaisuuksiin perustuva vallan logiikka kyseenalaistuu (Soja 2011, x). Irien oivallus hänen vielä syntymättömän lapsensa paikattomuudesta ja lapsen paikantamisen mahdottomuudesta perinteisessä mielessä, siis hegemonisen ja assimiloivan paikantamisen tarkoituksessa, toimii metaforana Irien voimalle muokata omaa tilaa. Irie ei tiedä, kumpi Iqbalien kaksospojista, Millat vai Magid ${ }^{12}$, on hänen lapsensa isä:

What she didn't know, and what she realized she may never know [- - ] was the identity of the father. No test on earth would tell her. Same thick black hair. Same twinkling eyes. Same habit of chewing the tops of pens. Same shoe size. Same deoxyribonucleic acid. She could not know her body's decision, what choice it had made, in the race to the gamete, between the saved and unsaved. She could not know if the choice would make any difference. Because whichever brother it was, it was the other too. She would never know. (WT, 515; kursiivi alkuperäinen.)

Kaksospojat toimivat tässä ikään kuin binaaristen vastakohtien kommentaarina ja heidän kauttaan ilmaistaan myös niihin sisältyvä kahtalaisuus ja ambivalenssi: ei ole mustaa ilman valkoista, ei varmuutta ilman epävarmuutta, ei kolonisoijaa ilman kolonisoitua eikä minää ilman Toista. Näihin vastapooleihin sisältyy kuitenkin aina murtumisen mahdollisuus juuri sen vuoksi, että toista ei voida ajatella ilman toista ja niinpä yksinapaisuus, yhden merkityksen kiinnittymiskohdan illuusio, on aina vaarassa särkyä ja kyseenalaistua.

Iriekaan ei aluksi kykene irrottautumaan tällaisesta vastakohtaparien kautta ajattelusta, jossa asiat määrittyvät hierarkkisesti eron kautta. Epävarmuus lapsen isästä saa Irien päättelemään, että ellei lapsi ole varmasti jonkun, se ei ole kenenkään:

At first this fact [epävarmuus isästä] seemed ineffably sad to Irie; instinctively she sentimentalized the biological facts, adding her own invalid syllogism: if it was not somebody's child, could it be that it was nobody's child? [- - ] That is how her child seemed. A perfectly plotted thing with no real coordinates. A map to imaginary fatherland. (WT, 515-516; kursiivi SR.)

Lainaus suorastaan pullistelee paikantumiseen viittaavista ja tilallisista metaforista; plotted-sana tarkoittaa Irien lapsen määritelmistä ja (ulkopuolisista) paikantamisista vapaata olemista. Lapsi on "perfectly plotted" eli täydellisen vapaa 'tontti' tai 'maapalanen', jolle ei ole rakennettu vielä minkäänlaista asutusta. ${ }^{13}$ Tätä seikkaa korostaa koordinaatteja vailla olemisen toistaminen, eikä lasta voikaan sijoittaa ennalta kuviteltuihin subjektin olemista määrittäviin diskursseihin, joihin tekstissä viitataan ilmaisulla "imaginary fatherland". Näin Irien määritelmiä pakeneva - mitä seikkaa myös lapsen syntymättömyys vielä osaltaan korostaa - lapsi kyseenalaistaa nuo ennalta määrätyt paikantumiset kahdellakin tapaa. Se, mitä paikantumisesta oletetaan, on lopulta vain 
kuvittelua ("imaginary") ja toisekseen olemalla määrittelemätön Irien lapsi tietysti kyseenalaistaa subjektin paikantamista koskevat, pakottavat yritykset.

Lopulta Irie oivaltaa, ettei sillä seikalla, kumpi pojista on lapsen isä, edes ole väliä: "[- - ] she thought: whatever, you know? Whatever" (WT; kursiivi alkuperäinen), sillä menneisyys ei määrää tulevaa ja tilaa voi muuttaa, joskaan ei tehdä "menneisyydettömäksi”, menneestä tyhjäksi. Teksti viittaa jälleen eksplisiittisesti tietämiseen: Irielle ei ole enää väliä sillä, tietääkö hän kumpi Iqbalien kaksospojista, Magid vai Millat, on hänen lapsensa isä. Tällä kertaa tietämistä koskevan "you know?” -ilmaisun esittäjänä on se, jota märittelyt on aiemmin ulkoapäin ulotettu koskemaan eli musta nainen. Nyt yhteisesti jaettuihin merkitysjärjestelmiin viittaa kuitenkin Irie itse, tosin ratkaisevasti eri tavalla kuin Hero ja kertoja aiemmin. Näin tapahtuu käytetyn kysymysmuodon vuoksi. Irie esittää tietämisen avoimena prosessina, tieto voi paikallistua hetkeksi, mutta kysymykset ovat jatkuvia ja jäävät lopulta avoimiksi. Voimme kenties tietää jotain hetkellisesti, voimme tehdä subjektiviteettia ja identiteettiä koskevia määrittelyjä ja merkityksellistämisiä eli paikantaa niitä, mutta nekin ovat aina väliaikaisia, valmiita muuntumaan ja jopa kumoutumaan. Niinpä Irie ymmärtää, että hänen täytyy piirtää oma karttansa, omat olemisen koordinaattinsa ja näin määritellä oma identiteettinsä ja suhteensa tilaan, olipa tuo tila sitten Englanti tai Karibianmeren ranta, jossa Irie romaanin lopuksi kuvataan lapsineen istumassa. Irie voi paikallistua moneen tilaan, olla kotonaan monessa eri paikassa, kunhan sulkeistavien määritelmien sijaan eteen avautuu avara meri. ${ }^{14}$

\section{Hetkelliseksi päätepisteeksi}

Tässä artikkelissa on pyritty kartoittamaan sitä, kuinka sukupuolen ja etnisyyden merkityksellistyminen on aina jollain tavoin sidoksissa ja suhteessa tilaan. Tilaa on hahmotettu sosiaalisesti tuotettuna, ennemminkin filosofisena kuin tiukan konkreettisena käsitteenä, jolloin se ei enää näyttäydy pelkkänä toiminnan taustana vaan osallistuu sosiaalisiin ja kulttuurisiin merkityksenantoprosesseihin.

Artikkeli on rakentunut kolmen keskeisen tietämistä koskevan sitaatin ympärille. Ensimmäinen kolmeen pisteeseen päättyvä "you know..." merkitsee rodullistettujen ja sukupuolitettujen subjektiasemien esiin tuomista, mutta myös katkosta siinä ajattelussa, jossa ihmisiä näin paikannetaan. Tästä hegemonisen paikantamisen kyseenlaistumisesta kertovat ilmaisun epäröivät pisteet sekä se, ettei henkilö, jonka toivotaan yhteinen merkitysjärjestelmä jakavan, ymmärräkään sitä.

Toisena on käsitelty ilmaisua "oh, you know her" sidoksissa kansallisuuteen, siihen tilaan, jota asuttavat englantilaiset ja josta yksi White Teeth -romaanin päähenkilöistä, Irie Jones, ei kykene itseään tunnistamaan. Foucault'n heterotopian ja utopian käsitteiden kautta on analysoitu etnisyyden ja kansallisuuden suhdetta ja tuotu esiin, kuinka eheän kansakunnan assimiloiva ajatus asetetaan teoksessa kyseenalaiseksi. Tuo ajatus 
kyseenalaistuu sekä peilin metaforan kautta että englantilaisen ruusun eli englantilaisen naisen ihannekuvan todellisuutta vastaamattoman luonteen kautta.

Viimeisessä luvussa on havainnoitu muutosta tietämistä koskevien "you know” -lausumien esittäjissä ja siinä, kuinka Irie Jonesin itsensä esittämä kysymysmuotoon puettu "you know?" -lausahdus jättää subjektiviteettia ja identiteettiä koskevat sulkeistavat määritelmät kyseenalaisiksi. Vaikka tyhjän tilan toive - siis toive voida täysin kieltäytyä näistä minää koskevistä, ulkoa käsin annetuista määritelmistä, ikään kuin elää irrallaan maailmamme ja kulttuuri(e)mme merkitysjärjestelmistä - näyttäytyy mahdottomuutena, niin jättämällä tietämistä koskevan ilmaisun lopun avoimeksi kysymysmerkillä teksti ehdottaa, että vastarinnan tiloja todella löytyy. ${ }^{15}$

\section{Viitteet}

${ }^{1}$ Vaivautuneisuutta implikoivat tässä katkonainen puhe, jota merkitään kolmella pisteellä, sekä sanojen tapailu. Lisäksi eksplisiittisillä maininnoilla Kelvin Heron hikoilusta ja vaikeuksista ilmaista asiaansa Archielle (WT, 70-72) ilmaistaan samaa Heron kokemaa hankalaa oloa. ${ }^{2}$ Clara on Archieta nuorempi; heidän mennessään naimisiin Clara on yhdeksäntoista ja Archie neljäkymmentäseitsemänvuotias (WT, 26).

${ }^{3}$ Haluaisin kiittää ruumiillisuutta koskevasta huomista Sanna Karkulehtoa.

${ }^{4}$ Kiitän tästä huomautuksesta Suvi Ronkaista.

${ }^{5}$ Enoch Powell oli brittiläinen konservatiivinen oikeistopoliitikko, joka vaati jyrkkiä rajoituksia maahanmuuttoon sekä kannusti jo maassa olevia siirtolaisia palaamaan lähtömaihin (BBC, 2007).

${ }^{6}$ Muun muassa Mindi McMann $(2012,624)$ on huomauttanut, kuinka White Teethissä rasismia käsitellään juuri Heron kaltaisten henkilöhahmojen kautta.

${ }^{7}$ Vaikka kertoja toimiikin tässä fokalisoijana, niin en puhu kertojasta. On tietenkin mahdollista, että puhujana on kertoja, joka on tietoinen siitä, että sekä ruskea, keltainen että valkoinen voivat saada konnotaation 'vieras'. Tällöin voidaan yksinkertaisesti vain puhua kertoja-fokalisoijasta. Koska kuitenkin on yhtä lailla mahdollista ja teoksen tematiikan kannalta yhteensopivaa, että halutaan ravistella ja purkaa vakiintuneita katsontakantoja (valkoinen-keskus-subjekti vs. musta-periferia-objekti), niin voidaan - vaikkakin vain implisiittisesti - havaita sellainen fokalisoija, joka ei arvioi valkoisuutta normiksi (vrt. Herman 2002, 309-330 hypoteettisesta fokalisaatiosta). Teoreettisesti tällainen erottelu on tässä mielekästä sen vuoksi, että se tuo edellä esitettyä kertoja-näkemystä painokkaammin esiin erilaiset vierautta koskevat "katsontapaikat".

${ }^{8}$ Ulrike Tancke $(2013,32)$ on huomioinut mielenkiintoisesti leikkikentän ambivalentin luonteen tilana, joka yhtälltä on avoin ja vapaa luokkahuoneen rajoituksista. Toisaalta leikkikenttä kuitenkin on usein valvonnan alaista tilaa, joka on aidoin erotettu ja rajattu omaksi alueekseen.

${ }^{9}$ Mindi McMann (2012, 629-630) on käsitteellistänyt Irien vartaloa abjektina ja todennut, että oma ruumis näyttäytyy Irielle jonain, joka hänen on hylättävä tullakseen osaksi yhteiskuntaa. Koska Irien kerrotaan perineen nämä hänet normatiivisesta englantilaisesta naiseudesta erottavat muotonsa sukunsa naisilta, tarkoittaa niiden hylkääminen myös tämän matrilineaarisen yhteyden menettämistä. 
${ }^{10}$ Kiitän Jopi Nymania "englantilaisen ruusun" eri merkitysten osoittamisesta.

${ }^{11}$ Kerronnallisella ulkopuolisuudella tarkoitan tässä, sitä, että kertoja on se, joka määrittelee naiset eivätkä määrittelijöinä toimi Irie tai "englantilainen ruusu” itse.

${ }^{12}$ Magidiin ja Millatiin liittyy mielenkiintoinen tilallinen ilmiö, sillä heidän isänsä Samad Iqbal lähettää Magidin opiskelemaan Bangladeshiin Millatin jäädessä Englantiin. Samadin mielestä länsimainen kulttuuri korruptoi ja turmelee hänen poikansa. Samad toivookin voivansa "pelastaa" edes toisen kaksosista (ja samalla kenties itsensä) lähettämällä Magidin opiskelemaan entiseen kotimaahansa. Kohtalo tuntuu kuitenkin pitävän Samadia pilkkanaan, sillä Englantiin jäänyt Millat kiinnostuu lopulta yhä enemmän radikaalista islamista. Kun Magid taas saapuu takaisin, Samad saa todeta, että Magidista on tullut tieteen edistyksen nimeen vannova anglofiili (ks. lisää esim. Dawson 2007, 162-165).

${ }^{13}$ Kiitän Jopi Nymania plotted-sanan monimerkityksisyyttä koskevista huomioista.

${ }^{14}$ Muun muassa Nick Bentley $(2007,496)$ on argumentoinut - Stuart Hallin uuden etnisyyden ('New Ethnicities') käsitettä soveltaen - että Irie ja erityisesti hänen vielä syntymätön lapsensa toimivat tällaisten etnisyyden uusien merkitysten symboleina.

${ }^{15}$ Kiitän artikkelikäsikirjoitukseni arvioineita refereitä monista tärkeistä huomioista sekä analyysia laajentaneista ja syventäneistä huomautuksista ja ideoista.

\section{Kirjallisuus}

Ashcroft, Bill, Gareth Griffiths \& Helen Tiffin 1995. Introduction to Part Thirteen: Place. Bill Ashcroft, Gareth Griffiths \& Helen Tiffin (eds.), The Postcolonial Studies Reader. London and New York: Routledge, 391-393.

BBC, 2007. On This Day 1950-2005. 20 April: 1968: Powell Slates Immigration Policy. http://news.bbc.co.uk/onthisday/hi/dates/stories/april/20/ newsid_2489000/2489357.stm (3.9.2014).

Bentley, Nick 2007. Re-Writing Englishness. Imagining the Nation in Julian Barnes's England, England and Zadie Smith's White Teeth. Textual Practice 21 (3), 483504.

Buchanan, Brad 2013. 'The Gift that Keeps on Giving': Zadie Smith's White Teeth and the Posthuman. Philip Tew (ed.), Reading Zadie Smith. The First Decade and Beyond. London et al.: Bloomsbury, 13-25.

Buchholz, Sabine \& Manfred Jahn 2005. Space in Narrative. David Herman, Manfred Jahn \& Marie-Laure Ryan (eds.), Routledge Encyclopedia of Narrative Theory. London \& New York: Routledge, Taylor \& Francis Group, 551-555.

Dawson, Ashley 2007. Mongrel Nation. Diasporic Culture and the Making of Postcolonial Britain. Ann Arbor: The University of Michigan Press.

Encyclopaedia Britannica 2014. Rose. http://global.britannica.com/EBchecked/ topic/509710/rose (11.12.2014).

Ellam, Julie \& Guy Woodward 2013 (2007). Zadie Smith made an astonishing literary debut with White Teeth (2002). British Council. Literature. http:/lliterature. britishcouncil.org/zadie-smith (3.9.2014). 
Foucault, Michel 1986. Of Other Spaces. (Des Espaces Autres, 1984). Trans. Jay Miskowiec. Diacritics 16 (1), 22-27.

Haraway, Donna 1988. Situated Knowledges. The Science Questions in Feminism and the Privilege of Partial Perspective. Feminist Studies 14 (3), 575-599.

Herman, David 2002. Story Logic. Problems and Possibilities of Narrative. Nebraska: University of Nebraska.

Higonnet, Margaret R. 1994. New Cartographies, an Introduction. Margaret R. Higonnet \& Joan Templeton (eds.), Reconfigured Spheres. Feminist Explorations of Literary Space. Amherst: University of Massachusetts Press, 1-19.

Karkulehto, Sanna, Tuija Saresma, Hannele Harjunen \& Johanna Kantola 2012. Intersektionaalisuus metodologiana ja performatiivisen intersektionaalisuuden haaste. Naistutkimus 25 (4), 17-28.

Kurikka, Kaisa (toim.) 1998. Paikkoja ja tiloja suomalaisessa kirjallisuudessa. Turku: Turun yliopisto, Taiteiden tutkimuksen laitos, 7-11.

Kymäläinen Päivi 2006. Paikan ajattelun haasteita. Seppo Knuuttila, Pekka Laaksonen \& Ulla Piela (toim.), Paikka. Eletty, kuviteltu, kerrottu. Helsinki: SKS, 201-217.

Lehtonen, Mikko \& Olli Löytty 2007. Suomiko toista maata? Joel Kuortti, Mikko Lehtonen \& Olli Löytty (toim.), Kolonialismin jäljet. Keskustat, periferiat ja Suomi. Helsinki: Gaudeamus, 105-118.

Lefebvre, Henri 1991. The Production of Space. (Production de l'espace, 1974.) Trans. Donald Nicholson-Smith. Malden et al.: Blackwell Publishing.

Lykke, Nina 2010. Feminist Studies. A Guide to Intersectional Theory, Methodology and Writing. New York and London: Routledge, Taylor \& Francis Group.

Massey, Doreen 2008. Samanaikainen tila. Toim. Mikko Lehtonen, Pekka Rantanen \& Jarno Valkonen. Suom. Janne Rovio. Tampere: Vastapaino.

McDowell, Linda 1999. Gender, Identity and Place. Understanding Feminist Geographies. Cambridge \& Oxford: Polity Press.

McDowell, Linda \& Joanne P. Sharp (eds.) 1997. Space, Gender, Knowledge. Feminist Readings. London et al.: Arnold.

McMann, Mindi 2012. British Black Box: A Return to Race and Science in Zadie Smith's White Teeth. Modern Fiction Studies 58 (3), 616-636.

Mirza, Heidi Safia 1997. Introduction. Mapping a Genealogy of Black British Feminism. Heidi Safia Mirza (ed.), Black British Feminism. A Reader. London \& New York: Routledge, 3-28.

Mirze, Z. Esra 2008. Fundamental Differences in Zadie Smith's White Teeth. Tracey L. Walters (ed.), Zadie Smith. Critical Essays. New York et al.: Peter Lang, 187-200.

Moss, Laura 2003. The Politics of Everyday Hybridity: Zadie Smith's White Teeth. Wasafiri 18:39, 11-17. 
Palin, Tutta 2004 (1996). Ruumis. Anu Koivunen \& Marianne Liljeström (toim.), Avainsanat. 10 askelta feministiseen tutkimukseen. Tampere: Vastapaino.

Paproth, Matthew 2008. The Flipping Coin: The Modernist and Postmodernist Zadie Smith. Tracey L. Walters (ed.), Zadie Smith. Critical Essays. New York et al.: Peter Lang, 9-29.

Rossi, Leena-Maija 2003. Heterotehdas. Televisiomainonta sukupuolituotantona. Helsinki: Gaudeamus.

Rossi, Leena-Maija 2010. Sukupuoli ja seksuaalisuus, erosta eroihin. Tuija Saresma, Leena-Maija Rossi \& Tuula Juvonen, Käsikirja sukupuoleen. Tampere: Vastapaino, 21-38.

Smith, Zadie 2000. Valkoiset hampaat. (White Teeth). Suom. Irmeli Ruuska. Toinen painos. Helsinki: Werner Söderström Osakeyhtiö.

Smith, Zadie 2000. White Teeth. London et al.: Penguin Books.

Squires, Claire 2002. Zadie Smith's White Teeth. A Reader's Guide. New York \& London: Continuum.

Soja, Edward W. 1996. Thirdspace. Journeys to Los Angeles and Other Real-and-Imagined Places. Malden et al.: Blackwell Publishing.

Soja, Edward 2011. Foreword. Andrew Teverson \& Sara Upstone (eds.), Postcolonial Spaces. The Politics of Place in Contemporary Culture. Houndmills et al.: Palgrave Mcmillan, ix-xvi.

Tancke, Ulrike 2013. White Teeth Reconsidered: Narrative Deception and Uncomfortable Truths. Philip Tew (ed.), Reading Zadie Smith. The First Decade and Beyond. London et al.: Bloomsbury, 27-38.

Tally, Robert T. Jr 2013. Spatiality. London \& New York: Routledge.

Teverson, Andrew \& Sara Upstone 2011. Introduction. Andrew Teverson \& Sara Upstone (eds.), Postcolonial Spaces. The Politics of Place in Contemporary Culture. Houndmills et al.: Palgrave Mcmillan, 1-13.

Tew, Philip 2010. Zadie Smith. New York, Houndmills et al.: Palgrave Macmillan.

Upstone, Sara 2009. Spatial Politics in the Postcolonial Novel. Farnham \& Burlington: Ashgate.

Valentine, Gill 2007. Theorizing and Researching Intersectionality: A Challenge for Feminist Geography. The Professional Geographer 59 (1), 10-21.

Walters, Tracey L., 2008. Introduction. Tracey L. Walters (ed.), Zadie Smith. Critical Essays. New York et al.: Peter Lang, 1-6. 